Annals of Warsaw University of Life Sciences - SGGW

Land Reclamation No 47 (4), 2015: 343-354

(Ann. Warsaw Univ. of Life Sci. - SGGW, Land Reclam. 47 (4), 2015)

\title{
Structure of radiation balance in diverse types of relief
}

\author{
ZBIGNIEW CAPUTA ${ }^{1}$, JAKUB WOJKOWSKI ${ }^{2}$ \\ ${ }^{1}$ Department of Climatology, University of Silesia in Katowice \\ ${ }^{2}$ Department of Ecology, Climatology and Air Protectio, University of Agriculture in Krakow
}

\begin{abstract}
Structure of radiation balance in diverse types of relief. The article presents the results of research on the structure of radiation balance in the full spectrum in diverse types of relief. The study was carried out on the Kraków-Częstochowa Upland (Poland). The varying terrain, its forms, expositions and slopes, large denivelations, and the varying land cover and land use make this small area very diverse as far as radiation conditions are concerned. On the basis of an actinometrical study the structure of radiation balance was assessed in two distinct morphologic terrain forms: the bottom of the valley and the plateau. It was proved that the global solar radiation $(K \downarrow)$ reaching the bottom of the valley in one year was on average $15 \%$ lower than the solar energy reaching the plateau. The all wave radiation balance $\left(Q^{*}\right)$ at the bottom of the valley was $16 \%$ less than on the plateau. The result of complex radiation conditions in the diversified relief was the occurrence of a mosaic of plant groups with distinct requirements.
\end{abstract}

Key words: radiation balance, solar radiation, long-wave radiation, topoclimate, Kraków-Częstochowa Upland

\section{INTRODUCTION}

The radiation balance plays an important role in forming the climatic conditions of a given area. Daily and annual air temperature, humidity, local pressure differences and the movement of air depend on it. The balance influences many processes taking place on the earth's surface such as the intense processes on-going in plants (vegetation, transpiration), soil (infiltration), rocks (insolation weathering) and surface water (evaporation). Knowledge of the radiation balance structure is essential in research on thermal and water balance, and very important not only in agriculture but also in other areas of life and economy.

A lot of international research can be found on the structure of the radiation balance and analyses of the different factors shaping its elements and their values (Beljaars and Holstaga 1991, Oke 1995, Gilgen et al. 1998, Liepert 2002, Geiger et al. 2003, Pozo-Vazques et al. 2004, Hicke 2005, Rottman et al. 2005, Romanou et al. 2007, Wild et al. 2008, Abdusamatov et al. 2012). In Poland, radiation balance is also the subject of many studies. There are a lot of articles about the influence of land cover and use on the structure of the radiation balance (Paszyński 1966, Olecki 1989, Paszyński et al. 1999, Błażejczyk 2004, Szymanowski 2004, Pawlak et al. 2005, Wojkowski and Caputa 2009, Fortuniak 2010). The influence of atmospheric circulation on solar radiation (Niedziałek 1983, Kożuchowski and Marciniak 1986, Dubicka 1997, Uscka-Kowalkowska 2007, Wojkowski and 
Skowera 2007), the impact of air masses and their transparency on direct solar radiation (Olecki 1992, Uscka-Kowalkowska 2007), and the influence of cloudiness on solar radiation (Matuszko 2009, Podstawczyńska 2010) have also been researched widely. The relation between solar radiation components with evapotranspiration (Bryś 2004), air and soil temperature (Bryś 2004, Kossowski 2007, Caputa and Wojkowski 2013) air pollution (Wójcik 1971, Hess and Olecki 1980, Kozłowska-Szczęsna and Podogrocki 1995) and the North Atlantic Oscillation index - NAO (Bryś 2007) are also of continuing interest.

Most of the above-mentioned works were prepared on the basis of actinometrical measurements and were carried out in one location, which did not allow generalised conclusions to be drawn about the spatial distribution of radiation balance components, especially on diverse relief. That is why the authors of the present paper decided to analyse the structure of such components on diverse relief. The main aim of the research was to evaluate the quantity differences of radiation balance components between the summit of an open plateau and the bottom of deep valleys. The research was prepared on the basis of multiannual measurements and actinometrical observations carried out on the upland diverse relief.

\section{MATERIAL AND METHODS}

In this evaluation, data from the years 2007 to 2012 from two meteorological stations situated on diverse geomorphological reliefs in the southern part of the Kraków-Częstochowa Upland were used (Fig. 1). The distance between stations is $3.2 \mathrm{~km}$ and the height difference was over $160 \mathrm{~m}$. The first station is in Ojców, in the middle of the bottom of the deep Prądnik valley at $322 \mathrm{~m}$ a.s.1. (1949'44" E, $\left.50^{\circ} 12^{\prime} 35^{\prime \prime} \mathrm{N}\right)$. It characterises the climatic conditions of the bottom of valleys and deep glens. The station is situated in the part of the valley directed to the north and south. It is characterized by a flat bottom and steep slopes, which are of east and west in aspect. The width of the valley bottom is about $150 \mathrm{~m}$ and the depth comes to $100 \mathrm{~m}$. The surface is overgrown with short grass. This location is characterised by very high horizon obstruction (Sky View Factor). The topographical horizon

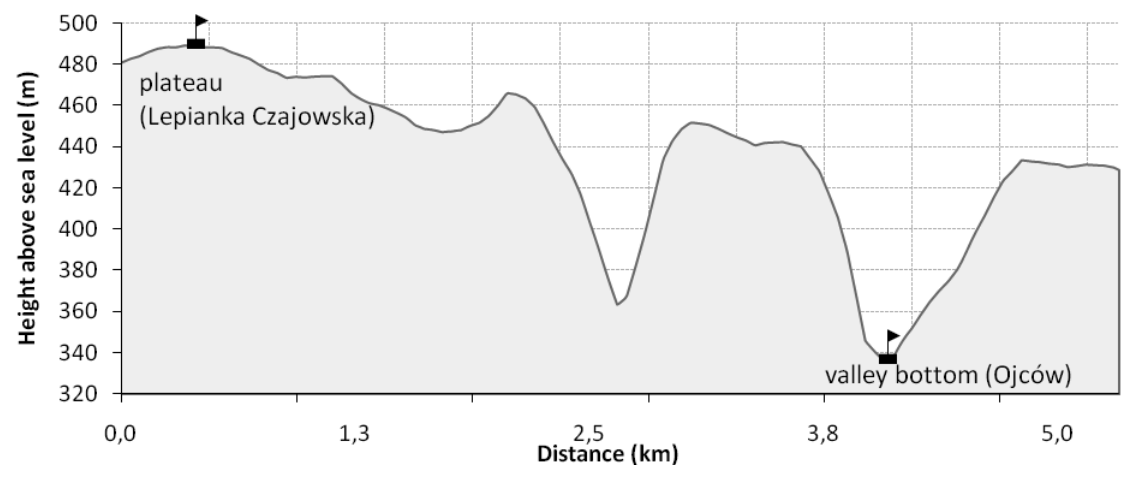

FIGURE 1. Location of meteorological stations in the profile of the study area 

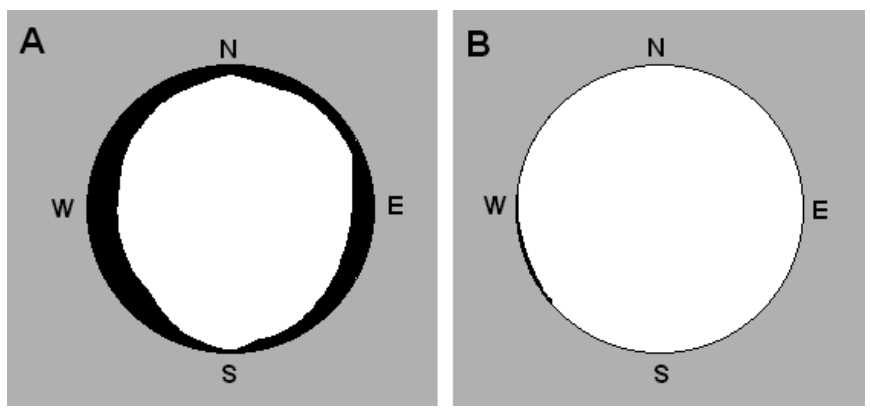

FIGURE 2. Horizon obstruction at the valley bottom in Ojców (A) and at the plateau in Lepianka Czajowska (B)

covers up $24 \%$ of the hemisphere (Fig. 2). The horizon is covered mostly in the west and east directions.

The second station is situated in the village of Lepianka Czajowska on a flat area of Jurassic plateau at $483 \mathrm{~m}$ a.s.1. $\left(50^{\circ} 12^{\prime} 23^{\prime \prime} \mathrm{N}, 19^{\circ} 47^{\prime} 04^{\prime \prime} \mathrm{E}\right)$. This location is characterised by very low horizon obstruction and typifies the climatic conditions in the highest parts of the upland well. The topographical horizon covers almost $2 \%$ of the hemisphere mainly in the west direction (Fig. 2). The station is overgrown with short grass, just like in Ojców.

Both stations were equipped with differential radiometers (CNR1 by Kipp \& Zonnen, a Vaisala multisensor WXT50 and Pt100 thermometers). The sensors were situated $1.5 \mathrm{~m}$ above the ground. The measurements were taken every $1 \mathrm{~min}$ and the mean values every $10 \mathrm{~min}$ were recorded. The sensors were calibrated by the producer and during the research additional periodic comparison of their readings was prepared. That enabled the exploration of the radiation conditions (structure and course) as well as the quantity characteristics of the topoclimatic differences of the upland.
Standard statistical methods were used to calculate the daily, monthly and mean long-term values for the analysed radiation fluxes.

\section{RESULTS AND DISCUSSION}

The mean monthly sums of the radiation balance components which were measured from 2007 to 2012 at the plateau are shown in Table 1 and those for the bottom of the valley in Table 2 . To show the difference between the bottom of the valley and the plateau, the percentage ratio of radiation at the bottom and on the plateau was calculated (Table 3 ). The sums of the radiation balance components on the plateau were assumed to be $100 \%$.

The research and actinometric observation conducted on the upland showed that in a year the flat non-shaded part of the plateau received on average 3,898 $\mathrm{MJ} \cdot \mathrm{m}^{-2}$ of global solar radiation $(K \downarrow)$. At the same time, due to significant horizon obstruction, the bottom of the valley received about $15 \%$ less solar energy than the plateau. High monthly components of $300 \mathrm{MJ} \cdot \mathrm{m}^{-2}$ from May to September were the main reason for the high annual 
TABLE 1 . Mean monthly and annual values of balance components at the plateau in the period 2007-2012 by monthly measurements

\begin{tabular}{|c|c|c|c|c|c|c|c|c|c|c|c|c|c|}
\hline \multirow{2}{*}{$\begin{array}{l}\text { Balance } \\
\text { components } \\
\left(\mathrm{MJ} \cdot \mathrm{m}^{-2}\right)\end{array}$} & \multicolumn{13}{|c|}{ Month } \\
\hline & I & II & III & IV & V & VI & VII & VIII & IX & $X$ & XI & XII & Year \\
\hline$K \downarrow$ & 80 & 158 & 306 & 489 & 490 & 572 & 578 & 519 & 338 & 189 & 117 & 62 & 3898 \\
\hline $\mathrm{K} \uparrow$ & 52 & 92 & 86 & 77 & 89 & 99 & 89 & 83 & 54 & 34 & 21 & 27 & 803 \\
\hline $\mathrm{L} \downarrow$ & 764 & 666 & 757 & 794 & 811 & 915 & 979 & 962 & 849 & 823 & 800 & 736 & 9856 \\
\hline $\mathrm{L} \uparrow$ & 785 & 704 & 856 & 940 & 916 & 1032 & 1096 & 1081 & 947 & 884 & 853 & 761 & 10854 \\
\hline $\mathrm{K}^{*}$ & 29 & 66 & 221 & 412 & 400 & 473 & 490 & 436 & 284 & 155 & 97 & 36 & 3099 \\
\hline $\mathrm{L}^{*}$ & -21 & -37 & -99 & -146 & -105 & -118 & -117 & -125 & -104 & -64 & -53 & -25 & -1013 \\
\hline $\mathrm{Q}^{*}$ & 8 & 29 & 122 & 264 & 290 & 321 & 373 & 311 & 180 & 91 & 44 & 12 & 2044 \\
\hline
\end{tabular}

TABLE 2. Mean monthly and annual values of balance components at the valley bottom in the period 2007-2012 by monthly measurements

\begin{tabular}{|c|c|c|c|c|c|c|c|c|c|c|c|c|c|}
\hline \multirow{2}{*}{$\begin{array}{l}\text { Balance } \\
\text { components } \\
\left(\mathrm{MJ} \cdot \mathrm{m}^{-2}\right)\end{array}$} & \multicolumn{13}{|c|}{ Month } \\
\hline & I & II & III & IV & $\mathrm{V}$ & VI & VII & VIII & IX & $\mathrm{X}$ & XI & XII & Year \\
\hline$K \downarrow$ & 66 & 121 & 243 & 396 & 485 & 489 & 507 & 448 & 277 & 159 & 82 & 51 & 3324 \\
\hline $\mathrm{K} \uparrow$ & 45 & 71 & 65 & 78 & 104 & 96 & 108 & 101 & 57 & 35 & 20 & 27 & 807 \\
\hline $\mathrm{L} \downarrow$ & 777 & 693 & 784 & 812 & 912 & 940 & 1000 & 982 & 901 & 866 & 809 & 781 & 10256 \\
\hline $\mathrm{L} \uparrow$ & 792 & 726 & 861 & 921 & 1011 & 1039 & 1093 & 1072 & 976 & 924 & 849 & 801 & 11066 \\
\hline $\mathrm{K}^{*}$ & 21 & 50 & 179 & 318 & 381 & 392 & 400 & 347 & 220 & 124 & 62 & 24 & 2517 \\
\hline $\mathrm{L}^{*}$ & -15 & -33 & -77 & -110 & -99 & -99 & -93 & -90 & -75 & -58 & -41 & -20 & -810 \\
\hline $\mathrm{Q}^{*}$ & 6 & 16 & 101 & 208 & 281 & 294 & 306 & 257 & 145 & 66 & 22 & 4 & 1707 \\
\hline
\end{tabular}

TABLE 3. Percentage ratio balance components at the valley bottom and at the plateau in the period 2007-2012 by monthly measurements

\begin{tabular}{|c|c|c|c|c|c|c|c|c|c|c|c|c|c|}
\hline \multirow{2}{*}{$\begin{array}{l}\text { Balance } \\
\text { components } \\
(\%)\end{array}$} & \multicolumn{13}{|c|}{ Month } \\
\hline & I & II & III & IV & V & VI & VII & VIII & IX & $X$ & XI & XII & Year \\
\hline$K \downarrow$ & 83 & 76 & 79 & 81 & 99 & 86 & 88 & 86 & 82 & 84 & 70 & 82 & 85 \\
\hline $\mathrm{K} \uparrow$ & 87 & 77 & 75 & 101 & 117 & 97 & 121 & 121 & 104 & 103 & 96 & 101 & 100 \\
\hline $\mathrm{L} \downarrow$ & 102 & 104 & 104 & 102 & 112 & 103 & 102 & 102 & 106 & 105 & 101 & 106 & 104 \\
\hline $\mathrm{L} \uparrow$ & 101 & 103 & 101 & 98 & 110 & 101 & 100 & 99 & 103 & 105 & 100 & 105 & 102 \\
\hline $\mathrm{K}^{*}$ & 74 & 75 & 81 & 77 & 95 & 83 & 82 & 80 & 77 & 80 & 64 & 65 & 81 \\
\hline $\mathrm{L}^{*}$ & 73 & 90 & 78 & 75 & 95 & 84 & 80 & 72 & 72 & 91 & 77 & 79 & 80 \\
\hline $\mathrm{Q}^{*}$ & 77 & 56 & 83 & 79 & 97 & 91 & 82 & 83 & 81 & 73 & 49 & 36 & 84 \\
\hline
\end{tabular}


values of the flux $K \downarrow$ on the plateau. At the bottom of the valley the value of the flux $K \downarrow$ was higher only from May to August (Fig. 3). The winter months were characterised by lower values of $K \downarrow$ both on the plateau and in the valley because of the low sun elevation over the horizon and much higher diffuse solar radiation in $K \downarrow$.

\section{A}

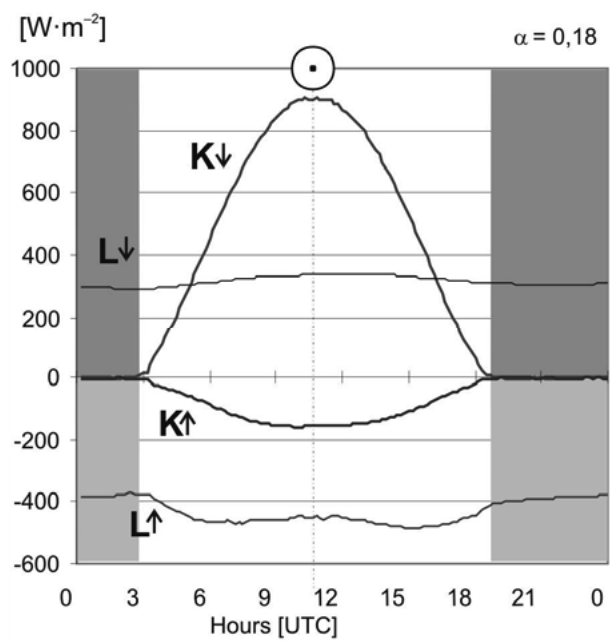

$\left[\mathrm{W} \cdot \mathrm{m}^{-2}\right]$

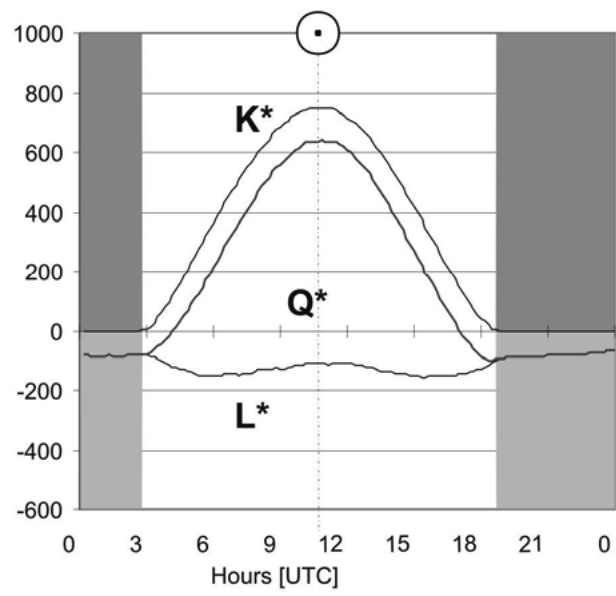

Part of $K \downarrow$ was reflected from the earth's surface as $K \uparrow$. During the year the value of the annual components of $K \uparrow$ on the plateau and at the bottom of the valley was similar at 803 and $807 \mathrm{MJ} \cdot \mathrm{m}^{-2}$, respectively. The rest of the energy $K \downarrow$ was used to heat the earth's surface, evaporation, the flux of heat of the soil, biological processes, etc. So-called absorbed

\section{B}

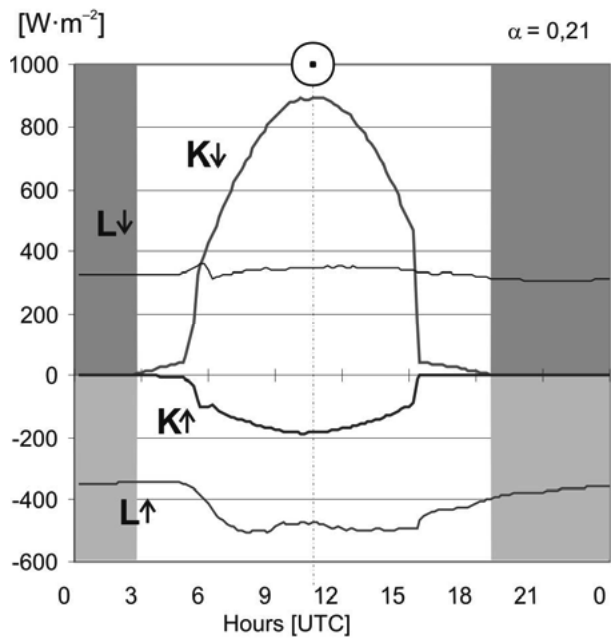

$\left[\mathrm{W} \cdot \mathrm{m}^{-2}\right]$

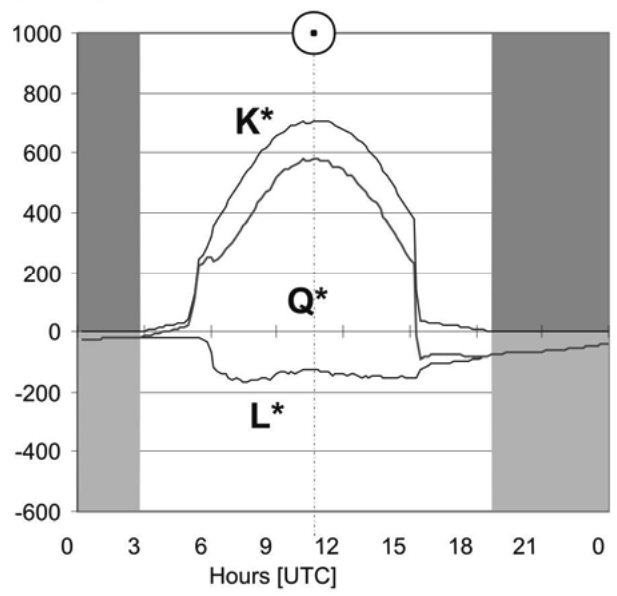

FIGURE 3. Daily course of radiation intensity at the plateau (A) and at the valley bottom (B) in the summer $(02.06 .2008)$ 
solar radiation was calculated according to the equation:

$$
K^{*}=K \downarrow-K \uparrow
$$

On the plateau the net short-wave radiation $K^{*}$ during the year amounted to $3,099 \mathrm{MJ} \cdot \mathrm{m}^{-2}$, whereas at the bottom of the valley the observed values were $19 \%$ lower.

In the case of long-wave radiation the situation was reversed. The bottom of the valley was characterised by higher radiation components of the atmosphere $L \downarrow$ than the plateau. The value of the flux $L \downarrow$ at the bottom amounted to $10,256 \mathrm{MJ} \cdot \mathrm{m}^{-2}$ whereas at the plateau it was $4 \%$ lower, because of the steep slopes of the valley, air humidity, fog and mist, the latter of which sometimes persisted for the whole day. Similarly, earth radiation $(L \uparrow)$ was higher at the bottom of the valley than at the plateau. The average value of the flux $L \uparrow$ at the bottom during the year was about $11,066 \mathrm{MJ} \cdot \mathrm{m}^{-2}$ whereas at the plateau it was $2 \%$ lower. The energy exchange between the atmosphere and the earth's surface in the long wave was calculated and shown as the net long-wave radiation, described by the following equation:

$$
L^{*}=L \downarrow-L \uparrow
$$

The net $L^{*}$ had negative values in the study period and over a year amounted to $-1,013 \mathrm{MJ} \cdot \mathrm{m}^{-2}$ at the plateau and $810 \mathrm{MJ} \cdot \mathrm{m}^{-2}$ at the bottom. The negative values of $L^{*}$ showed that outgoing long-wave radiation was high and resulted in the cooling of the earth's surface. That radiation was more intense at the plateau. From April to September the value of the net $L^{*}$ at the plateau was higher than $-100 \mathrm{MJ} \cdot \mathrm{m}^{-2}$ whereas at the bottom of the valley that value was higher only in April. Values of $L^{*}$ were lower at the bottom in the entire study period because of the lower radiation flux caused by humid air.

The all-wave radiation balance was calculated as follows:

$$
Q^{*}=K \downarrow-K \uparrow+L \downarrow-L \uparrow
$$

At the plateau the mean annual net $Q^{*}$ had a value of $2,044 \mathrm{MJ} \cdot \mathrm{m}^{-2}$. The highest value of $Q^{*}, 373 \mathrm{MJ} \cdot \mathrm{m}^{-2}$, was observed in July and the lowest, $8 \mathrm{MJ} \cdot \mathrm{m}^{-2}$, in January. High net values $Q^{*}$, higher than $100 \mathrm{MJ} \cdot \mathrm{m}^{-2}$ from April to September, were connected with the intense heating of the earth's surface.

At the valley bottom the mean annual net balance $\left(Q^{*}\right)$ had a value of $1,707 \mathrm{MJ} \cdot \mathrm{m}^{-2}$ and was $16 \%$ lower than at the plateau. That was because the flux $K \downarrow$ was limited by the slope obscuring the sun, especially in the morning and evening, and because of lower values of absorbed solar radiation $\left(K^{*}\right)$. The all-wave radiation balance $\left(Q^{*}\right)$ at the valley bottom was higher than $300 \mathrm{MJ} \cdot \mathrm{m}^{-2}$ only in July. Its lower values were observed in winter and autumn when the sun was low and obscured by fog and mist.

The daily highest values of radiation and great diversity in the radiation balance were observed during periods of high pressure with a clear sky and with a very weak or no wind at all (Oke 1995). That is why typical sunny days in the winter and summer were chosen to present the radiation contrast between the plateau and the bottom of the valley.

The daily global solar radiation $K \downarrow$ presented in Figures 3 and 4 was connected with the changes in the sun's position over the horizon. It was interrupted by morning fog and mist, which are quite 

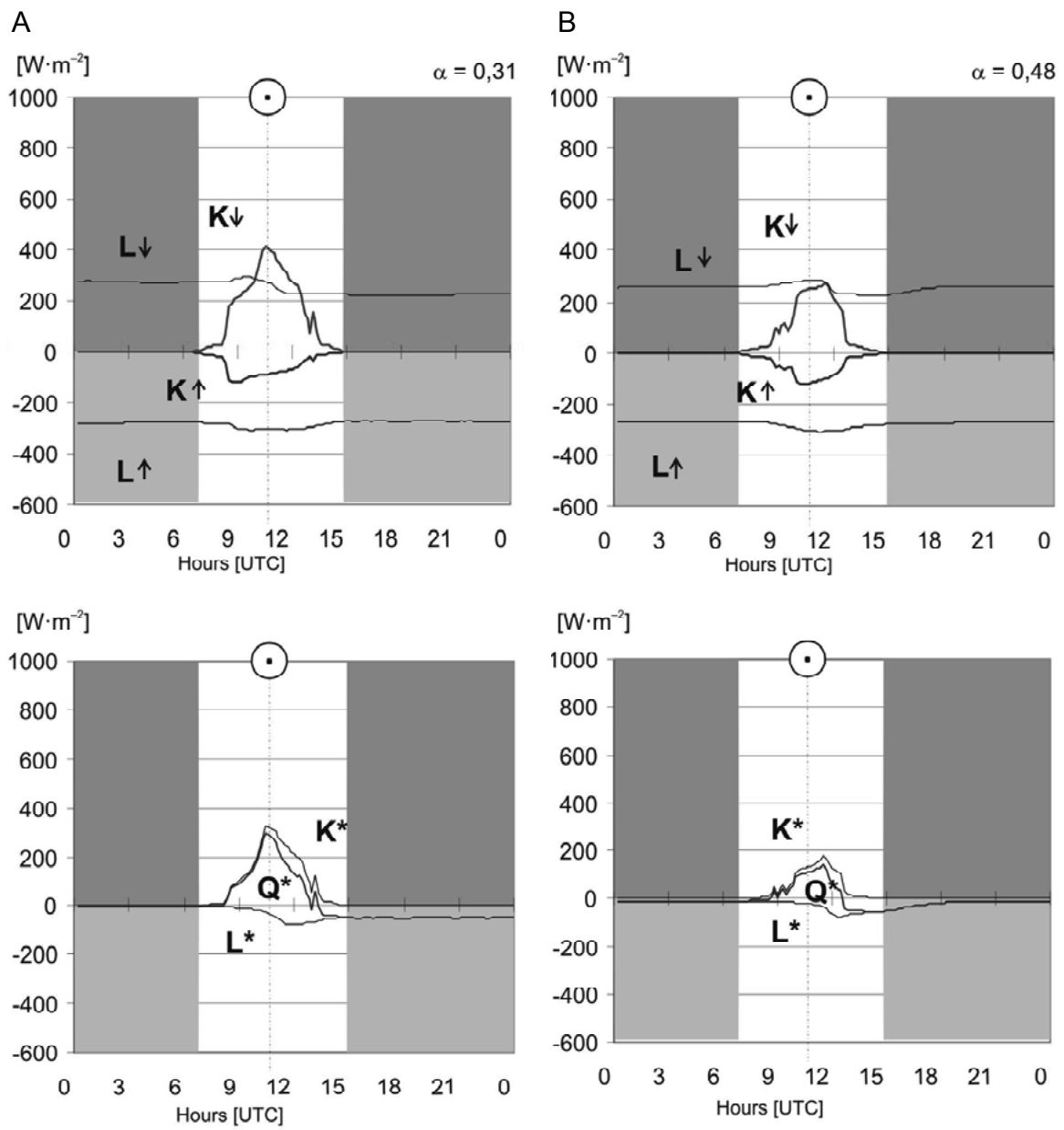

FIGURE 4. Daily course of radiation intensity at the plateau (A) and at the valley bottom (B) in the winter (30.12.2008)

common in winter. Around noon the air transparency improved; however, the fog could still remain at the bottom of the valley. The radiation $K \downarrow$ at the bottom of the valley was limited by steep slopes and additionally was weaker because of the high air humidity. On a sunny summer's day (2 June 2008) the daily component $K \downarrow$ at the bottom of the valley was $13 \%$ lower than at the plateau (Fig. 5). Big differences in the solar radiation flow were also observed in winter when the sun was low over the horizon (Fig. 4). On a winter's day (30 December 2008) the daily sum of flux $K \downarrow$ was $40 \%$ lower than at the plateau because of an obscured horizon and morning and evening fog (Fig. 6).

The ability of the surface to reflect the sun's radiation (albedo) changed slightly during the day. To eliminate data error the data were collected, if $K \downarrow>70 \mathrm{~W} \cdot \mathrm{m}^{-2}$ and $K \downarrow>K \uparrow$ (Miara and Paszyński 1984). 
As far as valley is concerned, the factor that modifies the radiation balance is the phenomenon of multiple solar radiation reflected from the slopes and the bottom of the valley. This phenomenon may significantly increase the global solar radiation and at the same time may lower the valley albedo and influence the variability of the reflected solar radiation.

High albedo values, reaching over $90 \%$, were recorded in winter with a thick snow cover. During thaw and while the snow was covered with particulate matter, the albedo dropped to $30 \%$. In summer the measured albedo values were lower and, depending on the condition of vegetation, they ranged from 17 to $22 \%$.

The daily reflected solar radiation ( $K \uparrow)$ depended on the intensity of $K \downarrow$ and on the albedo of the earth's surface. In summer, on a sunny day (2 June 2008) in the morning and afternoon the value of $K \uparrow$ at the bottom of the valley was lower than at the plateau because of the limited $K \downarrow$, which consisted only of diffuse solar radiation (Fig. 3). The daily sum of flux $K \uparrow$ at the bottom of the valley was $5 \%$ lower than the value recorded on the same day at the plateau (Fig. 5). On a winter's day (30 December 2008) the
A

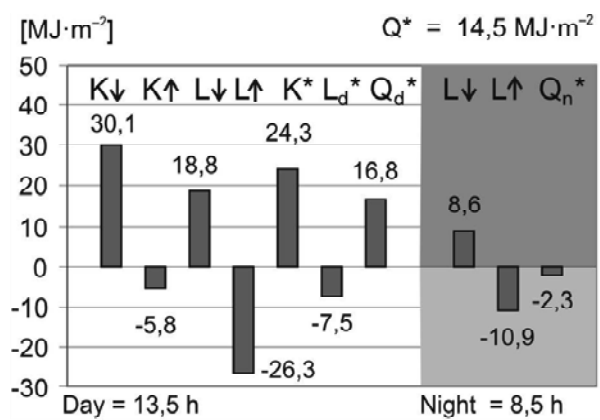

B

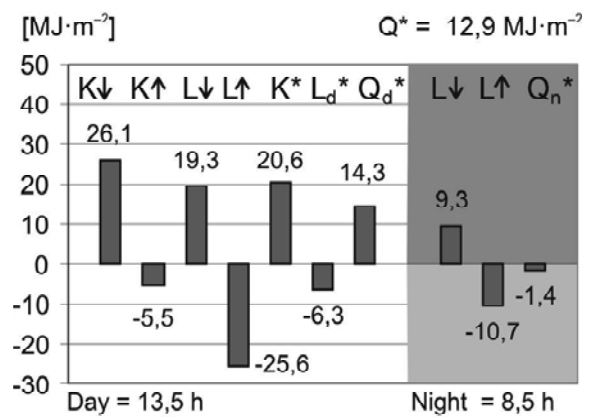

FIGURE 5. Structure of radiation balance at the plateau (A) and at the valley bottom (B) in the summer (02.06.2008)

A

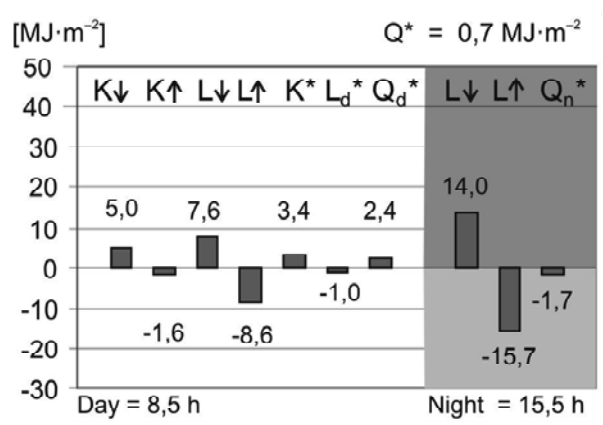

B

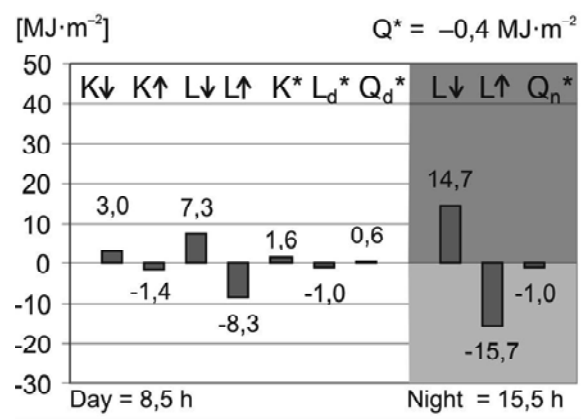

FIGURE 6. Structure of radiation balance at the plateau (A) and at the valley bottom (B) in the winter (30.12.2008) 
differences were bigger, reaching $13 \%$ (Fig. 6).

The absorbed solar radiation $\left(K^{*}\right)$ depended on $K \uparrow$ and $K \downarrow$. A considerable amount of energy $K \downarrow$ was absorbed by the earth's surface and transformed into thermal energy and used during the evaporation process. On a sunny day (2 June 2008) the value of the net $K^{*}$ at the bottom of the valley was $15 \%$ lower than at the plateau (Fig. 5), whereas in winter (30 December 2008) it was much bigger - at $53 \%$ (Fig. 6). As the albedo at the bottom of the valley and that at the plateau were similar, the differences in the net $K^{*}$ were caused by the obscured horizon at the bottom of the valley and low air transparency because of fog.

The course of incoming long-wave radiation $(L \downarrow)$ was characterised by the smallest changeability of the values among all the components of the radiation balance taking into consideration daily and annual values. The stable flow of $L \downarrow$ meant that there were minor fluctuations of temperature during the day and at night (Figs 3 and 4). Both in summer and in winter higher values of $L \downarrow$ were observed at the bottom of the valley. The daily sum of $L \downarrow$ at the bottom of the valley was usually a few per cent higher than on the plateau (Figs 5 and 6).

In the case of earth's surface long-wave radiation $(L \uparrow)$ the highest values were recorded during the day (Fig. 5). The influence of the wind speed on the cooling of the active surface was also observed. The highest values of $L \uparrow$ were measured when the wind speed was lower than $0.5 \mathrm{~m} \cdot \mathrm{s}^{-1}$. Outgoing long-wave radiation $(L \uparrow)$ at night and during the day was slightly higher on the plateau (Figs 5 and 6).
The negative values of net long-wave radiation $\left(L^{*}\right)$ showed cooling of the active surface. The earth's surface lost more heat because of the radiation than it received $L \downarrow$ from the atmosphere. The exchange of the energy between the atmosphere and the surface depended on the condition of the earth's surface and the vegetation, which prevented the soil from heating, although at the same time it prevented its heat loss. The cooling of the earth's surface $\left(L^{*}\right)$ was higher on the plateau especially in summer (Fig. 5). At the bottom of the valley, the cooling of the active surface was weaker because of high air humidity, which encouraged fog and limited the radiation of energy.

The all-wave radiation balance $\left(Q^{*}\right)$ received plus values in the day and negative ones at night. The biggest daily fluctuations of radiation balance were observed in summer (Fig. 3). In winter the daily changeability of the radiation balance was much smaller (Fig. 4). Both in summer and in winter the radiation balance values on the plateau were higher. On a sunny summer's day (2 June 2008), the daily radiation balance on the plateau was higher by $11 \%$ than the values observed at the bottom of the valley (Fig. 5). On a winter's day (30 December 2008), the difference between the daily radiation balance value on the plateau was much higher, at $-75 \%$ (Fig. 6 ).

\section{CONCLUSIONS}

The research on the all-wave radiation balance components in diversified relief showed great spatial changeability. The diversity of exposition and slopes, significant denivelations and also the variety of land cover and use enable a great diversity 
of radiation distribution to occur in a very small area. As shown in the research, the structure of the all-wave radiation balance in diverse relief depends on the factors which shape the insolation conditions. The geometry of the earth's surface, horizon obstruction, albedo, cloudiness and fog are among these factors. Concave terrain forms such as the bottoms of valleys and canyons are characterised by much lower balance values as regards the short-wave $\left(K^{*}\right)$ and long-wave $\left(L^{*}\right)$ spectrum in comparison with plateaus.

On the basis of the research the following conclusions can be drawn:

- The global solar radiation $(K \downarrow)$ reaching the bottom of the valley over the year was on average $15 \%$ lower than the solar energy that the plateau received.

- The absorbed solar radiation $\left(K^{*}\right)$ over a year at the bottom of the valley was $19 \%$ lower than the net on the plateau.

- Incoming long-wave radiation value $(L \downarrow)$ over a year was $4 \%$ higher at the bottom than radiation on the plateau.

- Net long-wave radiation value $\left(L^{*}\right)$ over a year was $20 \%$ lower at the bottom of the valley than on the plateau.

- The values of all-wave radiation balance $\left(Q^{*}\right)$ over a year at the bottom were $16 \%$ lower than on the plateau.

\section{REFERENCES}

ABDUSAMATOV KH. I. 2012: Bicentennial decrease of the solar constant leads to the Earth's unbalanced heat budget and deep climate cooling. Kinematics and Physics of Celestial Bodies. 28 (2), 62-68.

BELJAARS A.C.M., HOLTSLAG A.A.M. 1991: Flux parameterization over land surface for atmospheric models. J. Appl Meteor. 30, $327-$ -341 .
BŁAŻEJCZYK K. 2004: Radiation balance in man in various meteorological and geographical conditions. Geographia Polonica 77 (1), 63-76.

BRYŚ K. 2004: Wieloletnia zmienność termiki gleby we Wrocławiu-Swojcu i jej radiacyjne i cyrkulacyjne uwarunkowania [Long-term variability of soil temperature in Wrocław-Swojec and its radiation and circulation conditions]. Acta Agrophysica 3 (2), 209-219 (Engl. summ.).

BRYŚ K. 2007: Zmienność usłonecznienia we Wrocławiu-Swojcu w latach 1961-2006 na tle zmian sekularnych. Funkcjonowanie i monitoring geoekosystemów Polski w warunkach narastającej antropopresji [Variability of sunshine durations in Wroclaw-Swojec in the years 1961-2006 against secular changes. Operation and monitoring of Polish geoecosystems under increasing human pressure]. A. Kostrzewski, A. Andrzejewska (Eds). Biblioteka Monitoringu Środowiska Warszawa. GIOŚ, 243-255 (in Polish).

CAPUTA Z., WOJKOWSKI J. 2013: Wpływ promieniowania słonecznego na temperature powietrza i gleby na Wyżynie Krakowskiej [Influence of solar radiation on air and soil temperature in the Cracow Upland]. Prądnik. Prace Muz. Szafera 23, Ojców, 65-74 (in Polish).

DUBICKA M. 1997: Variation of sunshine duration in selected mountain regions of central Europe. Acta Universitatis Wratislaviensis, 1950, Prace Instytutu Geograficznego, C, Meteorologia i Klimatologia, 4, 31-41.

FORTUNIAK K. 2010: Radiacyjne i turbulencyjne składniki bilansu cieplnego terenów zurbanizowanych na przykładzie Łodzi [Radiation and turbulence components of the heat balance of urban areas on the example of Łódź]. Wyd. UŁ, Łódź, 232 (in Polish).

GEIGER R., ARON R.H., TODHUNTER P. 2003: The climate near the ground. 6th edit. Rowman \& Littlefield Publish, Oxford.

GILGEN H., WILD M., OHMURA A. 1998: Means and trends of shortwave irradiance at the surface estimated from GEBA. J. Clim. 11, 2042-2061.

HESS M., OLECKI Z. 1980: Wpływ zanieczyszczeń powietrza na stosunki radiacyjne w Krakowie [The impact of air pollution on radiation 
conditions in Krakow]. Zeszyty Naukowe UJ, Prace Geogr. 77, 29-43 (in Polish).

HICKE J.A. 2005: NCEP and GISS solar radiation data sets available for ecosystem modeling: Description, differences, and impacts on net primary production. Global Biogeochemical Cycles 19 (2).

KOSSOWSKI J. 2007: O relacji między strumieniem ciepła $\mathrm{w}$ glebie a promieniowaniem słonecznym [The relation between soil heat flux and solar radiation]. Acta Agrophysica 151, 10 (1), 121-135 (Engl. summ.).

KOZŁOWSKA-SZCZESNA T., PODOGROCKI J. 1995: Antropogeniczne zmiany warunków radiacyjnych w Warszawie [Anthropogenic changes in radiation conditions in Warsaw]. In: Klimat i bioklimat miast [Urban climate and bioclimate]. K. Kłysik (Ed.). Wyd. UŁ, Łódź, 87-97.

KOŻUCHOWSKI K., MARCINIAK K. 1986: Fluktuacje kontynentalizmu klimatu Polski na tle warunków cyrkulacyjnych i solarnych (1881-1980) [Climate fluctuations in Poland against the background of circulation and solar conditions (1881-1980)]. Przeglad Geofizyczny 2 (in Polish).

LIEPERT B.G. 2002: Observed reductions of surface solar radiation at sites in the United States and worldwide from 1961 to 1990. Geophysical Research Letters 29, 10.

MATUSZKO D. 2009: Wpływ zachmurzenia na usłonecznienie i całkowite promieniowanie słoneczne na przykładzie krakowskiej serii pomiarów [The influence of cloudiness on sunshine and global solar radiation on the example of the Cracow series of measurements]. Wydawnictwo UJ, Kraków (in Polish).

MIARA K., PASZYŃSKI J. 1984: Roczny przebieg albeda powierzchni trawiastej w Polsce [Annual course of grass albedo in Poland]. Przeglad Geograficzny 29 (3-4), 125-144 (in Polish).

NIEDZIAŁEK H. 1983: Bezpośrednie promieniowanie słoneczne $\mathrm{w}$ masach powietrznych w Puławach (1970-1975) [Direct solar radiation according to air masses in Puławy (1970 -1975)]. Folia Societatis Scientiarum Lublinensis 25, Geografia 1/2, 31-39 (in Polish).

OKE T.R. 1995: Boundary layer climates. Methuen, London.

OLECKI Z. 1989: Bilans promieniowania słonecznego w dorzeczu górnej Wisły [Radiation balance in the Upper Vistula basin]. Rozprawy Habilitacyjne UJ 0239-782X, 157 (in Polish).

OLECKI Z. 1992: Przezroczystość atmosfery w krakowskiej aglomeracji miejsko-przemysłowej [Atmospheric transmittance of urban-industrial agglomeration of Cracow]. Zeszyty Naukowe UJ, Prace Geogr. 90, 23-34 (in Polish).

PASZYŃSKI J. 1966: Atlas bilansu promieniowania w Polsce [Atlas of the radiation balance in Poland]. Dokumentacja Geograficzna 4 (in Polish).

PASZYŃSKI J., SKOCZEK J., MIARA K. 1999: Wymiana energii między atmosferą a podłożem jako podstawa kartowania topoklimatycznego [The energy exchange at the earth-atmosphere boundary as a base for topoclimatological mapping]. Dokumentacja Geograficzna 14. (in Polish).

PAWLAK W., FORTUNIAK K., PODSTAWCZYŃSKA A. 2005: The influence of urban canyon parameters on downward total solar radiation values - measurements and modelling, DWD. Annalen der Meteorologie 41(1), 200-203.

PODSTAWCZYŃSKA A. 2010: UV and global solar radiation in Łódź, Central Poland. Int. J. Climatol. 30, 1-10.

POZO-VAZQUES D., TOVAR-PESCADOR J., GÁMIZ-FORTIS S.R., ESTEBAN-PARRA M.J., CASTRO-DÍEZ Y. 2004: NAO and solar radiation variability in the European North Atlantic region. Geophysical Research Letters 31 (5).

ROMANOU A., LIEPERT B., SCHMIDT G.A., ROSSOW W.B., RUEDY R.A., ZHANG Y.C. 2007: 20th Century changes in surface solar irradiance in simulations and observations. Geophys. Res. Lett. 34.

ROTTMAN G.J., WOODS T., GEORGE V. 2005: The Solar Radiation and Climate Experiment (SORCE): Mission Description and Early Results. Springer, Vol. 230.

SZYMANOWSKI M. 2004: Miejska wyspa ciepła we Wrocławiu [Urban heat island of Wrocław]. Stud. Geogr. 77, 288 (in Polish).

USCKA-KOWALKOWSKA J. 2007: Ekstynkcja bezpośredniego promieniowania słonecznego w Puławach w latach 1969-1989 [Extinction by the atmosphere direct solar radiation in Puławy in the years 1969-1989]. Pamiętnik Puławski 144, 131-143 (in Polish). 
WILD M. 2009: Global dimming and brightening. Journal of Geophysical Research: Atmospheres (1984-2012) 114 (D10).

WOJKOWSKI J., CAPUTA Z. 2009: Przestrzenne i czasowe zróżnicowanie promieniowania pochłoniętego na obszarze Ojcowskiego Parku Narodowego. Prądnik [Spatial and temporal variation in absorbed radiation in the Ojców National Park]. Prace Muz. Szafera 19, Ojców, 169-180 (in Polish).

WOJKOWSKI J., SKOWERA B. 2007: Struktura bilansu promieniowania $\mathrm{w}$ wybranych typach sytuacji synoptycznych [The structure of the radiation balance dependent on synoptic situations]. Pamiętnik Puławski 144, 169-178 (in Polish).

WÓJCIK A. 1971: O wartościach bezpośredniego promieniowania słonecznego $\mathrm{w}$ warunkach atmosfery silnie zanieczyszczonej na przykładzie Górnośląskiego Okręgu Przemysłowego [On the value of direct solar radiation under conditions of heavy air pollution with the Upper Silesian Industrial District as an example]. Zesz. Nauk. Uniw. M. Kopernika w Toruniu, Nauki Mat.-Przyr. 26, 121-132 (in Polish).

Streszczenie: Struktura bilansu promieniowania $w$ warunkach urozmaiconej rzeźby terenu. Artykuł prezentuje wyniki badań struktury bilansu promieniowania w pełnym zakresie widma w warunkach urozmaiconej rzeźby terenu. Badania składowych bilansu promieniowania przeprowadzono na Wyżynie Krakowsko-Częstochowskiej. Urzeźbienie terenu, urozmaicenie form, ekspozycji i spadków, znaczne deniwelacje, a także różnorodność pokrycia i użytkowania sprawiaja że na stosunkowo małej przestrzeni występuje duże zróżnicowanie stosunków radiacyjnych. Na podstawie pomiarów aktynometrycznych określono strukturę bilansu promieniowania na dwóch odmiennych formach morfologicznych terenu, wierzchowinie i dnie doliny. Wykazano, że całkowite promieniowanie słoneczne $(K \downarrow)$ docierające do dna doliny w ciągu roku było średnio o $15 \%$ mniejsze od energii słonecznej, jaką otrzymywała wierzchowina. Bilans promieniowania w pełnym zakresie widma $\left(Q^{*}\right)$ osiagał na dnie doliny wartości mniejsze o $16 \%$ niż na wierzchowinie. Odzwierciedleniem złożonych stosunków radiacyjnych w warunkach urozmaiconej rzeźby terenu jest występowanie mozaiki zespołów roślinnych, o często zupełnie odmiennych wymogach siedliskowych.

Stowa kluczowe: bilans promieniowania, promieniowanie słoneczne, promieniowanie długofalowe, topoklimat, Wyżyna Krakowsko-Częstochowska

\section{MS. received November 2015}

\author{
Authors' address: \\ Jakub Wojkowski \\ Katedra Ekologii, Klimatologii i Ochrony \\ Powietrza \\ Uniwersytet Rolniczy w Krakowie \\ al. A. Mickiewicza 24/28, 30-059 Kraków \\ Poland \\ e-mail: rmwojkow@cyf-kr.edu.pl
}

